\title{
Distribution and habitat characteristics of Trichilia triacantha (Meliaceae) in Puerto Rico
}

\author{
Eduardo A. Ventosa-Febles* \\ Puerto Rico Department of Natural and Environmental Resources, Bureau of Fish and Wildlife, PO Box 3665, Marina Station, \\ Mayagüez, Puerto Rico 00681-3665
}

\begin{abstract}
The distribution and habitat characteristics of the endemic and endangered plant species Trichilia triacantha Urb. (Meliaceae) were studied in the southwestern region of Puerto Rico. Searches for populations and individuals started in 1992 and ended in 1996. These searches were done in areas where the species had been previously reported and at other potential population sites. We found 109 ind. distributed in 10 populations. This represents an increase of $172 \%$ in the number of individuals and $25 \%$ in the number of populations previously reported. Four populations were on private lands; 2 of them consisting of isolated individuals. The number of plants found in grouped populations varied from 2 to 35, with an average of 13.4. All the plants occurred in the Subtropical Dry Forest Life Zone, at an altitude of $175 \mathrm{~m}$ or less, and were growing on well-drained soils, such as those derived from limestone. Most individuals were found on the more mesic side of hills.
\end{abstract}

KEY WORDS: Endangered · Guánica · Trichilia $\cdot$ T. triacantha · Bariaco $\cdot$ Puerto Rico

\section{INTRODUCTION}

Trichilia triacantha Urb. (Meliaceae), commonly know as bariaco, is an evergreen shrub or small tree endemic to the island of Puerto Rico (US Fish and Wildlife Service 1991). It reaches 8 to $10 \mathrm{~m}$ in height and 1.5 to $2 \mathrm{~cm}$ in stem diameter (Vivaldi \& Woodbury 1981). The alternate leaves are pinnately compound, with 3 to 7 oblong or wedge-shaped leaflets (Fig. 1). The inflorescence is a panicle that may reach $4 \mathrm{~cm}$ in length (Fig. 2). Fruits are capsules with a red aril. It is limited to woodlands and thickets at low elevations in dry southwestern districts of the island (Liogier 1988). The species was declared endangered in February 1988, pursuant to the Endangered Species Act of 1973 (US Fish and Wildlife Service 1988).

Trichilia triacantha was first collected by Pleé in 1822 to 1823 from the Peñuelas area in southern Puerto Rico. It was collected in Guánica by Sintenis in 1886 and in 1939 by Gregory. Urban described the species on the basis of 3 specimens, 1 collected by Pleé (963) and 2 collected by Sintenis (3749 and 4813) (Urban
1903-1911). The original material studied by Urban was destroyed during World War II (Vivaldi \& Woodbury 1981). Pennington (1981) selected Sintenis 3749, collected near Guánica, as the lectotype. Subsequently, the species was not seen or collected until Woodbury rediscovered it in the 1960s (Vivaldi \& Woodbury 1981).

Trichilia triacantha is known from deciduous to semi-evergreen forests and woodlands in southern and southwestern Puerto Rico (Britton \& Wilson 1923, Liogier \& Martorell 1982, Liogier 1988). It has been reported from Guaniquilla (municipality of Cabo Rojo), the Guánica State Forest (municipality of Guánica and Yauco), Los Cedros (municipality of Guayanilla), and Peñuelas municipality. It is most abundant in Guánica at elevations below $100 \mathrm{~m}$, where it is mostly found along drainage areas (Vivaldi \& Woodbury 1981).

Information about the distribution and abundance of the species will influence future management decisions. Therefore, searches for new populations in Guánica, Guayanilla, Peñuelas, and other potential population sites were conducted. 


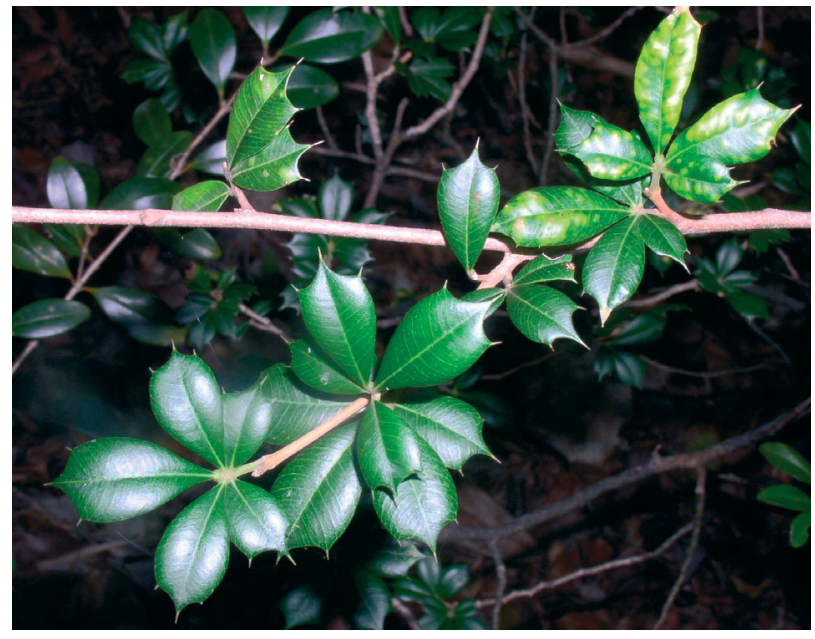

Fig. 1. Trichilia triacantha. Compound leaves of the plant in the Guánica Commonwealth Forest. Yellow leaves show some form of disease

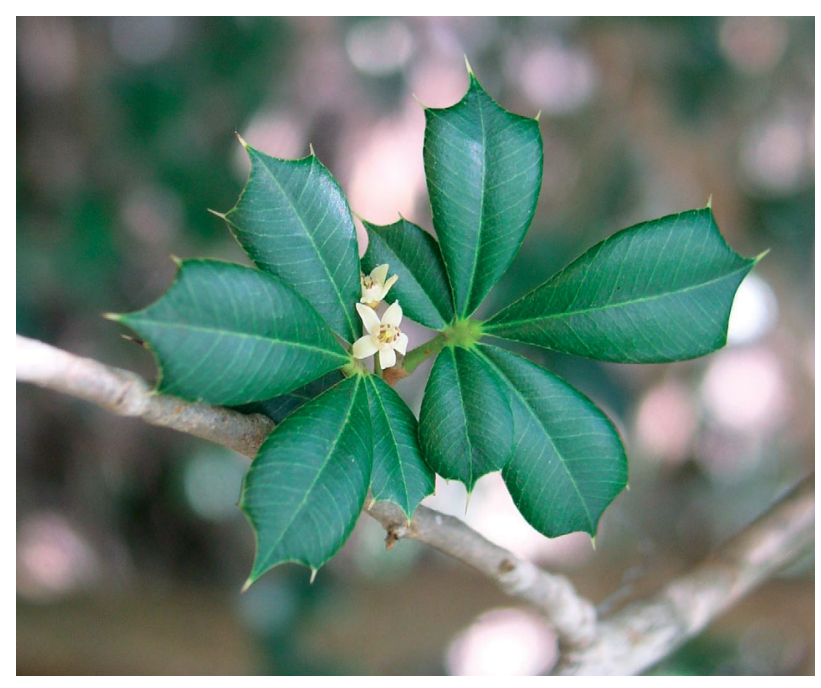

Fig. 2. Trichilia triacantha. Flower buds and mature flowers

\section{MATERIALS AND METHODS}

Trichilia triacantha was studied in all the municipalities where the species has previously been found (Cabo Rojo, Guánica, Yauco, Guayanilla and Peñuelas). Populations of $T$. triacantha were located by consulting published maps and reports or by interviewing local researchers, naturalists, and forest rangers. Searches were also done at potential population sites outside the known distribution of the species.

The number of individuals in each population was determined. The area around each population was examined for the occurrence of seedlings (germinated seed in soil surface) and saplings. Each individual was marked with a numbered aluminum tag and height, number of trunks, basal area, and reproductive status were recorded. Basal area (BA) was determined using the following equation: $\mathrm{BA}=1 / 4 \pi \Sigma d_{i}$, where $d_{i}$ is the diameter of the $i$ th trunk at the base. Plants that measured less than $1 \mathrm{~m}$ in height with a basal area less than $1 \mathrm{~cm}^{2}$ were classified as sapling or immature. Plants were classified as sterile (no reproductive structures) or breeding (evidence of reproductive structures).

Distances among individuals within populations were determined using a Fremaco Hip-Chain ${ }^{\circledR}$, with a capacity of $9999.9 \mathrm{~m}$ and an accuracy of $\pm 0.2 \%$, or a $100 \mathrm{~m}$ tape. Locations of populations were recorded with a Sony Pyxis IPS-360 Global Positioning System (GPS) and compared with the corresponding US Geological Survey topographical maps. The computer program ArcView v. 3.2 for Windows was used to build a georeference layer of Trichilia triacantha populations.

At each location, the following habitat parameters were recorded: elevation $(\mathrm{m})$, slope orientation $(\mathrm{N}, \mathrm{S}$, E, W), exposure (sunny, semi-shade or shady conditions), soil type, mean annual precipitation (mm) and temperature $\left({ }^{\circ} \mathrm{C}\right)$, vegetation life zone, associated tree species, and types of disturbance (e.g. fires, soil removal, selective cutting). Elevation was measured with a portable altimeter and exposure orientation was determined from topographical maps and a compass. Soil type was verified using soil maps of the US Department of Agriculture $(1965,1975,1979)$ Soil Surveys. The mean annual precipitation and temperature were based on the unpublished data of the Department of Natural and Environmental Resources pluviometer and thermometer, located in the Guánica State Forest (henceforth GSF), and on data from the US Environmental Data Service (1994). Potential vegetation life zones in the Holdridge system were determined using Ewel \& Whitmore's (1973) map of Puerto Rico. Types of disturbance were obtained through field observation and by interviewing the land managers or owners.

Spearman's test was used to determine correlation between the height and the basal area of individuals. A G-test for goodness for fit was used to determine significant differences among exposures of the sites occupied by Trichilia triacantha.

\section{RESULTS}

A total of 109 ind. were found in 10 wild populations of Trichilia triacantha (Fig. 3). Of these, 47 plants were fertile, 58 were infertile, and 4 were saplings. No seedlings were found. Only 1 individual located in the GSF died. 


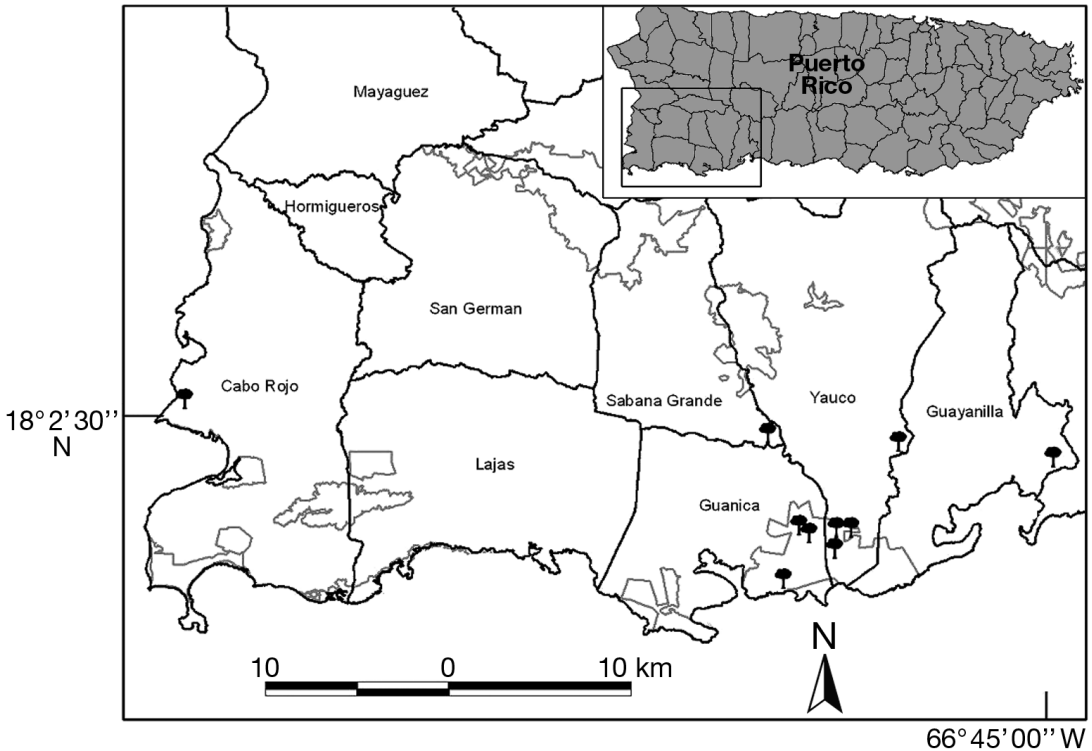

Fig. 3. Trichilia triacantha. Populations of the species (black 'trees') in the southwest of Puerto Rico. Black lines: municipalities; grey lines: refuges and reserves

From a total of 102 ind. measured, basal area ranged from 0.71 to $66.44 \mathrm{~cm}^{2}(\bar{x}=7.18, \mathrm{SD}=8.68)$. Fifty-four percent of the individuals had a basal area less than $5 \mathrm{~cm}^{2}$, while $43 \%$ were between 5 and $24 \mathrm{~cm}^{2}$. Only 3 plants had a basal area greater than $35 \mathrm{~cm}^{2}$. A positive and significant correlation was found between the height and the basal area of individuals (Spearman's correlation coefficient $r_{s}=0.81, p \leq 0.0001$ ).
Of the 10 populations, 4 were on private land ( 8 ind.) and 6 were in the GSF (101 ind.). The GSF is a 4000 ha reserve protected by the Commonwealth of Puerto Rico for over 60 yr. Originally, the GSF population was estimated at only 37 ind. Two of the 10 populations visited consisted of isolated individuals (plants in which pollen movement from other conspecific trees is highly improbable, due to the large distance to the nearest individual). These populations were in Yauco and Guayanilla. The distance between these isolated populations and conspecific trees was approximately $7 \mathrm{~km}$ for Yauco and $9 \mathrm{~km}$ for Guayanilla. The distance between conspecific trees among the 8 populations of grouped individuals ranged from 0.22 to $13.30 \mathrm{~m}$. The number of plants in populations consisting of grouped individuals ranges from 2 to 35 (mean, 13.4). All the plants found in the GSF were grouped individuals, and the 2 populations consisting of isolated individuals were found on private lands (Yauco and Guayanilla).

Trichilia triacantha grows on soils derived from limestone rock (Table 1). One population was found on a substrate of Americus fine sand, 3 populations were found on a substrate of San Germán cobbly loam, and 1 population on a substrate of Aguilita stony clay loam. All of these substrates are derived from limestone rock.

Table 1. Trichilia triacantha. Description of sites where T. triacantha occurs. MAP: mean annual precipitation; MAT: mean annual temperature; $\mathrm{m}$ a.s.l.: meters above sea level

\begin{tabular}{|c|c|c|c|c|c|c|}
\hline $\begin{array}{l}\text { Population } \\
\text { no. }\end{array}$ & $\begin{array}{c}\text { No. of } \\
\text { individuals }\end{array}$ & Municipality & $\begin{array}{l}\text { Elevation } \\
\text { (m a.s.l.) }\end{array}$ & $\begin{array}{l}\text { MAP } \\
(\mathrm{mm})\end{array}$ & $\begin{array}{l}\text { MAT } \\
\left({ }^{\circ} \mathrm{C}\right)\end{array}$ & $\begin{array}{l}\text { Substrate/ } \\
\text { derived from }\end{array}$ \\
\hline 1 & 3 & Cabo Rojo & 25 & 1941 & 25.2 & $\begin{array}{l}\text { Americus fine sand/ } \\
\text { limestone rock }\end{array}$ \\
\hline 2 & 22 & Guánica & 165 & 1278 & 26.8 & $\begin{array}{l}\text { Limestone rock land/ } \\
\text { limestone rock }\end{array}$ \\
\hline 3 & 35 & Guánica & 140 & 1278 & 26.8 & $\begin{array}{l}\text { Limestone rock land/ } \\
\text { limestone rock }\end{array}$ \\
\hline 4 & 2 & Guánica & 175 & 1278 & 26.8 & $\begin{array}{l}\text { Limestone rock land/ } \\
\text { limestone rock }\end{array}$ \\
\hline 5 & 4 & Yauco & 170 & 1278 & 26.8 & $\begin{array}{l}\text { Limestone rock land/ } \\
\text { limestone rock }\end{array}$ \\
\hline 6 & 26 & Yauco & 48 & 1278 & 26.8 & $\begin{array}{l}\text { Limestone rock land/ } \\
\text { limestone rock }\end{array}$ \\
\hline 7 & 12 & Yauco & 75 & 1372 & 25.2 & $\begin{array}{l}\text { Limestone rock land/ } \\
\text { limestone rock }\end{array}$ \\
\hline 8 & 1 & Yauco & 140 & 1372 & 25.2 & $\begin{array}{c}\text { San Germán cobbly loam/ } \\
\text { limestone rock }\end{array}$ \\
\hline 9 & 3 & Sabana Grande & 78 & 1372 & 25.2 & $\begin{array}{c}\text { San Germán cobbly loam/ } \\
\text { limestone rock }\end{array}$ \\
\hline 10 & 1 & Guayanilla & 50 & 1278 & 26.8 & $\begin{array}{c}\text { Aguilita stony clay loam/ } \\
\text { limestone rock }\end{array}$ \\
\hline
\end{tabular}


All populations were found growing at an elevation of $175 \mathrm{~m}$ or less (Table 1). The lowest elevation at which an individual was found was $25 \mathrm{~m}$ (Guaniquilla population). Mean annual precipitation varied from

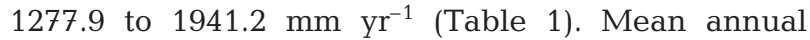
temperature ranged from 25.2 to $26.8^{\circ} \mathrm{C}$ (Table 1). All populations occurred in the deciduous and the semievergreen seasonal forest within the Subtropical Dry Forest Life Zone.

Trichilia triacantha tends to occur more on the mesic north to west facing slopes than on the drier south to east facing ones (Table 2). A significant difference was found in the exposure of the sites occupied by $T$. triacantha individuals ( $G$-test, $G=149.46, \mathrm{p}=0.05$, df $=7$ ). Sixty-one percent of the individuals occurred in sunny locations, over the forest canopy, and 39\% in semishade conditions, under the forest canopy. The plants that occurred in shady conditions tended to be immature or small shrubs.

A total of 16 plants species occurred together with Trichilia triacantha (Table 3). The species most frequently associated with $T$. triacantha were Bursera simaruba (L.) Sarg., Amyris elemifera L. and Coccoloba diversifolia Jacquin. The major threats to the populations found were selective cutting (probably for fence posts), soil removal (construction of trails), and pressure for tourist and residential development.

Table 2. Slope orientation: directions in which Trichilia tricantha face on the slopes where they grow in Puerto Rico

\begin{tabular}{|c|c|c|c|c|c|c|c|c|}
\hline & $\mathrm{N}$ & NE & $\mathrm{E}$ & $\mathrm{SE}$ & S & SW & W & NW \\
\hline Total & 3 & 12 & 16 & 0 & 12 & 3 & 3 & 60 \\
\hline
\end{tabular}

Table 3. Tree species found in association with the 10 known populations of Trichilia triacantha

\begin{tabular}{lc|} 
Plant species & $\begin{array}{c}\text { Frequency of occurrence } \\
\text { (total no. of populations) }\end{array}$ \\
\hline Bursera simaruba (L.) Sarg. & 10 \\
Amyris elemifera L. & 9 \\
Coccoloba diversifolia Jacq. & 9 \\
Bucida buceras L. & 7 \\
Erythroxylum aroelatum L. & 7 \\
Guaiacum officinale L. & 6 \\
Polygala cowellii (Britton) Blake & 4 \\
Randia aculeata L. & 4 \\
Zamia portoricencis Urb. & 3 \\
Agave missionum Trel. & 1 \\
Clusia rosea Jacq. & 1 \\
Eugenia biflora (L.) DC & 1 \\
Exostema caribaeum (Jacq.) J.A. Schultes & 1 \\
Leucaena leucocephala Lam. & 1 \\
Opuntia rubescens & 1 \\
Salm-Dyck ex De Candole & \\
Trichilia hirta L. & 1 \\
\hline
\end{tabular}

\section{DISCUSSION}

Originally, Trichilia triacantha was identified in the areas of Guaniquilla, Guánica, Guayanilla, and Peñuelas. In field surveys conducted during the present study, we found the Guaniquilla, GSF, and Guayanilla populations. The known abundance of $T$. triacantha has risen by over $170 \%$ since the preparation of the recovery plan for the species in 1991. From 40 ind. known at that time, that number has increased to 109 ind. located in 10 different populations. Also, 2 new populations were identified during this study (an increase of $25 \%$ ), one in the municipality of Sabana Grande and the other in Yauco. Thus, the new reports of individual plants in the present study expand the known range of the species.

During March 1997, Dr. Armando Urquiola, Dr. Isidro Méndez, and Mr. José Cedeño found a population of Trichilia triacantha in the municipality of Peñuelas, in a place known by locals as 'El Peñon', close to the municipality of Ponce. This population consists of 1 plant with 1 sapling. The plant was sterile. It was not determined if this population is a remnant of the one discovered by Pleé in 1822 to 1823 in the Peñuelas area.

Trichilia triacantha is highly restricted to soils derived from limestone. These soil types are well-drained substrates. All individuals occur in well-drained habitats such as cliffs and slopes. In addition to good drainage, the species occurs more on the mesic north to west facing slopes than on the drier south to east facing ones.

The species apparently requires exposure to light for reproduction; the plants that occur in shady conditions tend to be immature or small shrubs. All of the infertile individuals were found growing in shady conditions under the forest canopy, and fertile plants were found in sunny to semi-shade conditions (i.e. growing on forest margins or in the forest canopy).

Seed germination and establishment of Trichilia triacantha apparently requires 2 habitat disturbances. The first disturbance is characterized by the removal of soil surface (i.e. land slice, tree throw or fast moving water). The seed must be in contact with this exposed soil in order to germinate. The second disturbance required is gap formation (i.e. a broken branch or fallen tree) in order to increase the amount of light received by the saplings. Under these circumstances, an increased growth rate is expected that would allow the plant to reach maturation.

It appears that the juveniles of Trichilia triacantha are shade tolerant and that maturation may be a function of light availability. A similar finding was obtained in a recent study conducted in the same area. Rojas (1994) found that Polygala cowellii, a species restricted to limestone derived soils, had to reach the canopy layer to achieve maturity. 


\section{CONCLUSIONS AND RECOMMENDATIONS}

Trichilia triacantha is restricted to the southwest part of Puerto Rico, where it grows only in soil derived from limestone. T. triacantha is an endangered species, a status principally caused by the constant loss of habitat that has occurred in the subtropical dry forest of the southwest region of the island. This deforestation has occurred for agricultural or urban development. The species apparently requires 2 disturbances for seed germination and establishment: removal of soil surface and gap formation. Because no seedlings were found in the wild close to the parental plants, seeds may need to be dispersed away from the parental plant in order to germinate.

The fact that $80 \%$ of the known populations consist of grouped individuals suggests that there is a good potential for future generations to appear at the sites where these populations are currently found. However, the reality is that recruitment at these sites seems to be absent or taking place at a very low rate. The absence of seedlings and the relatively small number (4) of saplings found both indicate that recruitment may not be in equilibrium with mortality.

Because $93 \%(n=109)$ of Trichilia triacantha individuals are found in protected areas, recovery priorities should emphasize the protection of existing populations found outside protected areas. The protection of these populations will maintain genetic diversity and provide a source of propagative material. T. triacantha should continue to be listed as an endangered species. Although new individuals and populations were discovered during the course of this study, most of the sites where the species occurs are not under protected status.

Acknowledgements. I thank Dr. Duane Kolterman, Dr. Gary Breckon, Dr. Allen Lewis, Dr. Miguel García, Mr. Ricardo López-Ortiz, Mr. José Sustache and Mrs. Glorivee Carrero for their advice and comments on the manuscript. The following biologists provided assistance in the field: Ricardo LópezOrtiz, Arnaldo Falcón, José Camacho, Jeanine Vélez, José Cedeño, Oscar Vázquez, Gloria Rojas, Rudy O'Reilly, Dr. Eugenio Santiago, Vivian Santiago, Adanela Sisa, Alejandrina Mejía, and Sandra Gonzalez. Special thanks to Mr.

Editorial responsibility: Hans Juergen Boehmer, Munich, Germany
Rubén Padrón and Mr. Miguel Canals for providing valuable data on the distribution of Trichilia triacantha. Permits were given by the Puerto Rico Department of Natural and Environmental Resources. I also thank editors and anonymous reviewers for their suggestions.

\section{LITERATURE CITED}

Britton NL, Wilson P (1923) Botany of Porto Rico and the Virgin Islands, Vol 5. New York Academy of Sciences, New York

Ewel JJ, Whitmore JL (1973) The ecological life zones of Puerto Rico and the U.S. Virgin Islands. US Department of Agriculture Forest Service Research Publications, ITF-18, Rio Piedras

Liogier HA (1988) Descriptive flora of Puerto Rico and adjacent islands, Vol 2. Editorial de la Universidad de Puerto Rico, Río Piedras

Liogier HA, Martorell LF (1982) Flora of Puerto Rico and adjacent islands: a systematic synopsis. Editorial de la Universidad de Puerto Rico, Río Piedras

Pennington TD (1981) Meliaceae. Flora Neotropica Monograph 28. The New York Botanical Garden, Bronx, New York

Rojas GM (1994) Reproductive and population ecology of Polygala cowellii (Britton) Blake (Polygalaceae). MS thesis, University of Puerto Rico, Mayagüez

Urban I (1911) Symbolae Antillanae seu fundamenta flora Indiae Occidentalis, Vol 4. Paul Klincksieck, Paris

US Department of Agriculture (1965) Soil survey. Lajas Valley area, Puerto Rico. Series 1961 no. 23. Soil Conservation Service and University of Puerto Rico, College Agricultural Service, Rio Piedras

US Department of Agriculture (1975) Soil survey of Mayagüez area of western Puerto Rico. Soil Conservation Service and University of Puerto Rico, College Agricultural Service, Rio Piedras

US Department of Agriculture (1979) Soil survey of Ponce area of southern Puerto Rico. Soil Conservation Service and University of Puerto Rico, College Agricultural Service, Rio Piedras

US Environmental Data Service (1994) Climatological data for Puerto Rico and the Virgin Islands, Vol 40 (No. 12). National Climatic Data Center, Asheville, NC

US Fish and Wildlife Service (1988) Endangered and threatened wildlife and plants: determination of endangered status for the plant 'Trichilia triacantha' (Bariaco). Fed Regist 53:3565-3567

US Fish and Wildlife Service (1991) Bariaco (Trichilia triacantha) recovery plan. US Fish and Wildlife Service, Atlanta, GA

Vivaldi JL, Woodbury RO (1981) Status report on Trichilia triacantha. US Fish and Wildlife Service, Mayagüez

Submitted: June 12, 2007; Accepted: August 28, 2007

Proofs received from author(s): September 27, 2007 